\title{
VOTERS' PERCEPTION TOWARDS POLITICAL PARTY: A GEOSPATIAL CASE STUDY OF YOUNG VOTERS IN JOHOR BAHRU
}

\author{
N. Ismail ${ }^{1}$, M. F. Abdul Khanan ${ }^{1,{ }^{*}}$, M. Z. Abdul Rahman ${ }^{1}$, A. H. Md $\operatorname{Din}^{1}$, Z. Ismail ${ }^{1}$, A. N. Abdul $\operatorname{Razak}^{2}$ \\ ${ }^{1}$ Faculty of Built Environment and Survey, Universiti Teknologi Malaysia, Johor Bahru, Malaysia -* mdfaisal@utm.my \\ ${ }^{2}$ Faculty of Social Sciences and Humanities, Universiti Teknologi Malaysia, Johor Bahru Malaysia
}

KEY WORDS: Election, electoral geography, youth voters, political geography, GIS and spatial analysis.

\begin{abstract}
:
The application of Geographic Information System (GIS) and election is a study that stresses geospatial aspects which gives support to election boundaries, election information management system along with GIS analysis in election boundaries. This article, as a concept, explains the role and function of GIS and geopolitics as an introduction to examine the election pattern in Malaysia. This study was aimed at understanding the issue that influenced youth voters in DUN Nusajaya to cast their votes in General Election, thus charting new strategies for future election. In doing so, nine issues are carefully selected and analysed from a geographical perspective by using GIS method. Socio-demographic data, issues influenced and assessment of state political figure, are used to explore geographic variability in relationships between each variable at a detailed spatial level. Spatial analysis using geographically weighted regression (GWR) was employed, which enables the investigation of local variations in voting patterns. The results demonstrate that assessment of state political figures do vary over geographic space and some of the variables that are traditionally assumed affect certain locations.
\end{abstract}

\section{INTRODUCTION}

Elections are an essential component of any democratic society and are the conventional means by which a population selects individuals to represent them politically (Arrow 1951). The study on elections and voting behaviour in Malaysia began when Malaysia gained independence and continue until today (Nizah, 2016). He found that, it is based on researchers who have led a research in Malaysia through general elections, state elections and by-elections.

As the role of citizen is to participate in elections, the elections should be free and fair. Free and fair elections are essential to a democratic system of governance. Generally, citizens participate in the election process to express their voice as well as their right to elect officials to represent them in a government. In addition, through election, citizens as voters can choose their representatives in conditions of openness, equality and transparency that simulate political competition.

Voter turnout is widely viewed as an important indicator of 'the health of a democracy' (Franklin, 1999). There are various factors that affect participation of citizens to vote for their representatives in specific elections. Election campaigns vary in their intensity. Ezrow (2016) analysed voter turnout and its relationship to citizen satisfaction with democracy. It was found that cross-national empirical studies on voter turnout show that levels of citizen satisfaction are linked to voter turnout. The choices of voters in election are affected by various factors, especially social-group identify, which helps to forge enduring partisan identification. In addition, voters are influenced more by short-term factors such as issues, campaign events and candidate appeal (Nizah et al., 2016). Figure 1 shows one of election campaign in Malaysia.

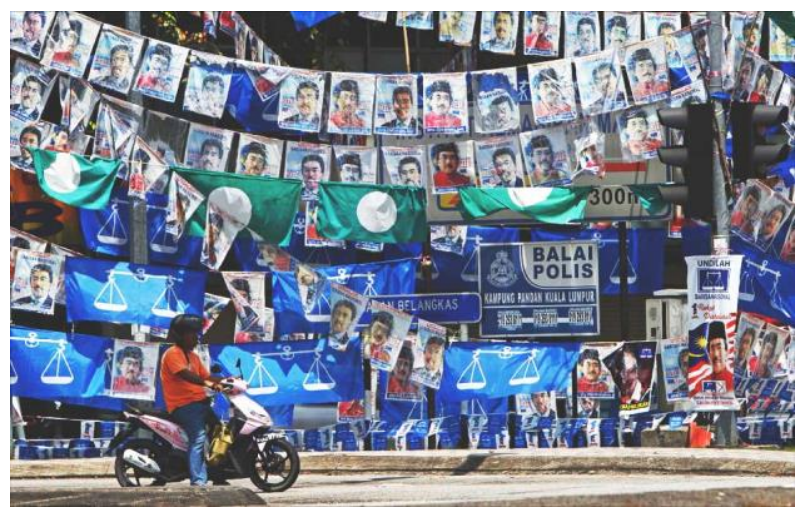

Figure 1. Election campaign in Malaysia

Nizah et. al (2016) found that most of the issues are pertaining to the social issues (i.e. water supply, law, education, free speech rights, role of media, road safety and university services). Nevertheless, they found that due to the influence of stakeholders, these social issues have become a political issue, and became agenda of some political parties. Therefore, different views are created, which turned into various perceptions. According to Nizah et. al (2016), voters' perception are affected by different issues. These issues can be in the form of ethnic sentiments, economic, and development or even news that formed perception for voters. One of political issues represented in Figure 2.

Perception of the voters often influence by issues that has been displayed during elections period. According to Ramani (2014), a survey from Daksh and the Association for Democratic Reforms completely surveys the basis of voters' perception and identifies background information such as gender, age, qualification, area, location, occupation, religion and assets. 


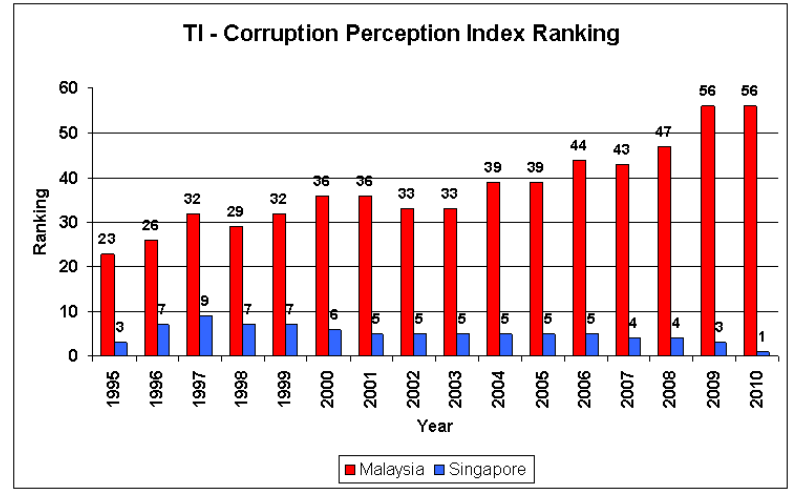

Figure 2. Example of political issue in Malaysia

He mentioned that by using GIS technology, one can achieve the general perception of the voters' decision in Indian cities and across the country by selecting only respondents who have been surveyed in selected location.

A review of the literature on the subject illustrates that the voting process can be more effective using GIS technology. However, there is still a lack of geospatial aspect according to voter perceptions especially among youth in Malaysia. Young people are growing increasingly frustrated by the continued socio-economic challenges that they face, such as unemployment, poor infrastructure (e.g. housing) and poor education (Tracey, n. d.). For this reason, government and other stakeholders need to find innovative strategies of accessing and engaging with the youth. Thus, political campaigns in Malaysia must acknowledge the differences of geographical, demographics, psychological and perception of the youth and first-time voters (Abd Rahim, 2017).

Awang Besar (2012) unveils the political perception among the Malays youth voters are crucial in determining the stability of political, social and economic situations. Three types of perception namely job prospect, economic improvement and social issues dominates youth Malay voters for voting. However, despite the comprehensiveness of issues presented, the article only represents the statistical result in textual and tabular which is a non-geographical aspect.

Recently, with a new evolution of technology in spatial analysis, Geographically Weighted Regression (GWR) has been introduced to solve such problems related to spatial nonstationary. Geographically Weighted Regression (GWR) is a regression method capable of handling various relationships of variables in local spatial patterns for modelling, examining, monitoring and decision making. This paper focus on the youth voters' perception towards political parties and issues influenced them by using Geographically Weighted Regression to develop spatial statistical models that can account for spatially varying relationships. Result of GWR analysis shown spatial pattern as represented in Figure 3. The aim is to explore to what extent can issues and political factors be used to explain ward-level variations in voters' perception and how these relationships vary over geographic space.

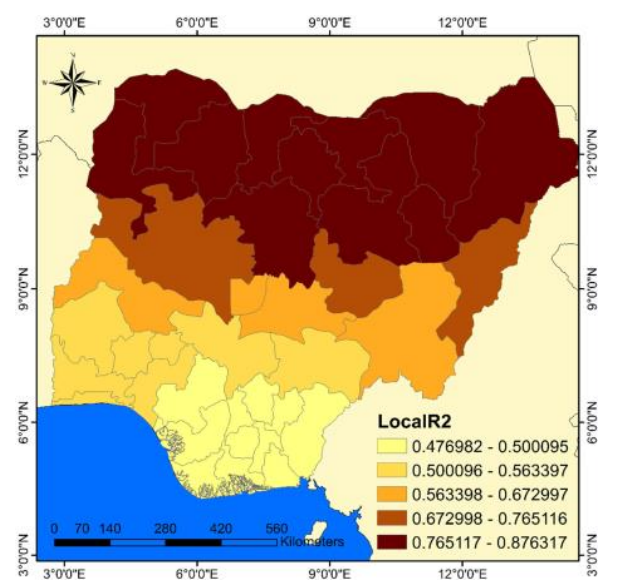

Figure 3. Local R2 smoothing for GWR showing model's fitness spatial variation

An election analysis has never been complete without a focused observation of voter perceptions and influential issues. Though in its early stages in Malaysia, previous studies on the subject were not entirely specific and had paid more attention in general to election results, party performance, campaign agenda and the issues involved (Faisal, 2002). However, there is still lack of research that focuses on the voters themselves and the external factors that helped shape their perceptions, such as the issues that directly concerned them and voting factors. In attempting to complement past research and also produce geospatial aspect, this study seeks to identify the issues that influence voter perceptions towards political parties in order to determine the future course of the Malaysian administration.

The primary aim of this study is to map the voters' perception by understanding the issues that influenced the perception of young voters in the general elections by focusing directly on young people. These are the objectives of this study to ensure that the aim of this study can be achieved:

i. To identify the specific issues which affects young voters' perception in Nusajaya.

ii. To establish a spatial relationship between political parties with the issues that influenced youth voters in Nusajaya.

iii. To produce map on youth voters' perception towards political parties in DUN Nusajaya.

\section{METHODOLOGY}

The methodology consists of four integral stages needed to achieve the aims. Figure 3 shows these stages in the form of flowchart where the explanation of this figure is in the subsequent sections. 


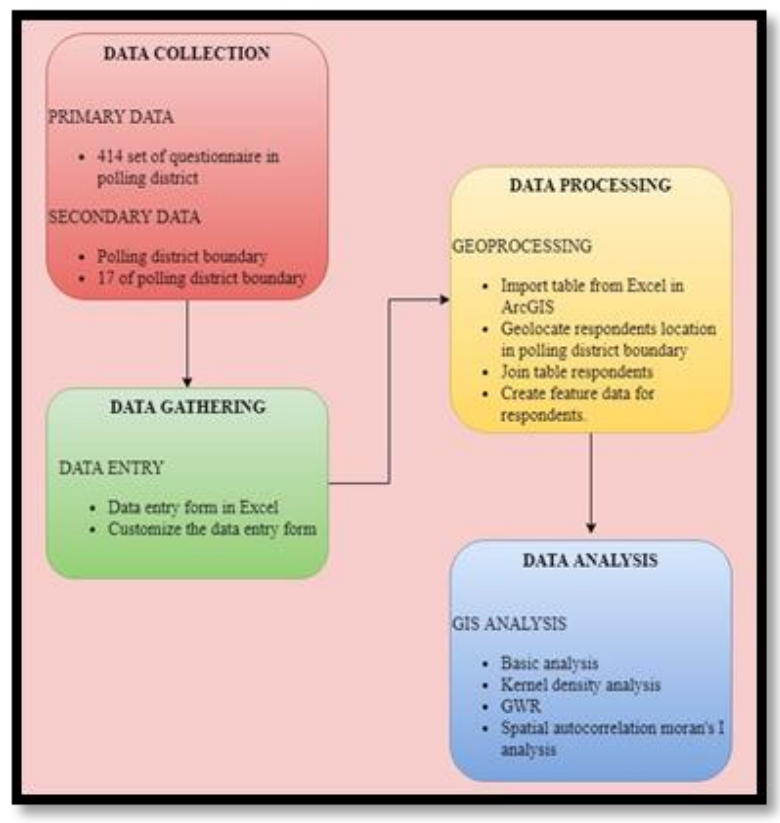

Figure 3. Overall flowchart of research methodology

\subsection{Case Study Area}

The specific case study area is Dewan Undangan Negeri or DUN Nusajaya, which falls under Parliamentary constituency of Gelang Patah under the old delineation. To note, DUN is the state constituency while Parliament is the federal constituency. The voters of Nusajaya are counted based on registration made before electoral process. As of March 2017, the total number of youth voters registered with the Election Comision (EC) in Nusajaya stood at 54,123 . According to EC, group that have been eligible to register as youth voters in Malaysia are those in the 21 to 40 years of age category. Figure 4 shows the map of the case study area which highlights the polling district included within DUN Nusajaya. Polling district is a much smaller unit of constituency compared to DUN.

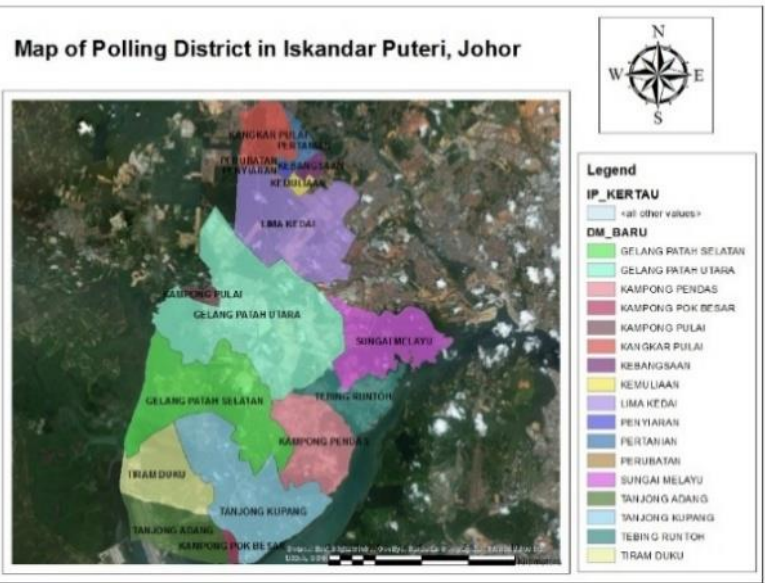

Figure 4. Polling district boundary in Nusajaya

\subsection{Mission Planning}

Prior to the data collection, the sample size required for this study was determined. The calculation of sample size is done by using an online calculator web application. In this study, the sample size required for Nusajaya is 382 and there are 17 polling districts in DUN Nusajaya.

A questionnaire entitled "Young Voters Perception Towards Political Parties in Johor Bahru" was designed and used in this study as the instrument with specific sections including personal data of the respondents, the issues influencing their perception, and others. The set of questionnaires is aimed to acknowledge the young voters' perception towards political parties. Questions relating to the influence of issues and the locality, perceived factors that affect voters' perception as well as possible strategies for political parties to enhance and advance their efforts on the parliaments involved are included. In order to have a complete questionnaire, participants were asked to tick demographic category.

\subsection{Data Collection}

There are two types of data used in this study which is primary data secondary data. For primary data, this study requires participants and questionnaire as instrument for data collection. Polling district boundary was obtained from TindakMalaysia website as a secondary data, which can be seen in Figure 4.

The questionnaire consisted of a number of questions drafted in short sentences. A structured questionnaire and close-ended techniques were used in order to give decision to respondents to fill in responses to the questions.

In this study, a total of 700 questionnaires were distributed and 660 questionnaires were returned; however, only 414 were usable for this study and met required inclusion criteria as discussed in the previous chapter. This represented $108 \%$ of the required sample. The remaining 246 questionnaires were deemed unusable as two or more subsections of the questionnaires were omitted. The number of completed questionnaire of each polling district can be shown in Table 1 .

\begin{tabular}{|c|c|c|c|}
\hline No & Polling District & $\begin{array}{l}\text { Number of } \\
\text { Questionnaire } \\
\text { s Distributed }\end{array}$ & $\begin{array}{l}\text { Number of } \\
\text { Questionnaire } \\
\text { s Returned } \\
\text { and } \\
\text { Completed }\end{array}$ \\
\hline 1. & Pertanian & 30 & 21 \\
\hline 2. & Penyiaran & 30 & 10 \\
\hline 3. & Kangkar Pulai & 120 & 77 \\
\hline 4. & Kampung Pok Besar & 30 & 20 \\
\hline 5. & Kampung Pulai & 30 & 20 \\
\hline 6. & Tanjong Kupang & 30 & 19 \\
\hline 7. & Kampong Pendas & 30 & 22 \\
\hline 8. & Kebangsaan & 30 & 21 \\
\hline 9. & Gelang Patah Utara & 30 & 21 \\
\hline 10. & $\begin{array}{ll}\text { Gelang } & \text { Patah } \\
\text { Selatan } & \end{array}$ & 30 & 23 \\
\hline 11. & Tanjong Adang & 30 & 23 \\
\hline 12. & Tiram Duku & 30 & 19 \\
\hline 13. & Kemuliaan & 30 & 18 \\
\hline 14. & Tebing Runtoh & 30 & 22 \\
\hline 15. & Sungai Melayu & 30 & 15 \\
\hline 16. & Lima Kedai & 60 & 41 \\
\hline 17. & Perubatan & 30 & 22 \\
\hline
\end{tabular}

Table 1. The number of completed questionnaire 


\subsection{Data Compilation}

The data collected from questionnaire was stored in Microsoft Excel spreadsheet. The spreadsheet is prepared for import into ArcGIS. Each record of respondents contains unique identity. In addition, all data are populated in each polling district. After the necessary preparations are made in the spreadsheet, it is ready for import in ArcGIS.

\subsection{Data Processing}

In order to map youth voters' perceptions in GIS, the data was spatially referenced. The longitude and latitude provide the necessary spatial references that define the locations of the respondents in polling district. These coordinated are in Kertau RSO.

After the tabular data is successfully imported into ArcGIS, function join is used to join between two or more tables in respondent and polling district layer. These layers are ready for spatial analysis in the subsequent stage.

\subsection{Data Analysis}

The purpose of qualitative and quantitative analysis is to interpret the data and the resulting themes, to facilitate understanding of the phenomenon being studied (Sargeant, 2012). Prior to any implementation of GIS analysis, a sequence of spatial analysis is important in this study in order to give better understanding and performance. The sequence of spatial analysis for this study can be seen as below:
I. Demographic statistical analysis
II. Kernel density analysis
III. GWR analysis
IV. Spatial autocorrelation Moran's I analysis

Thus, four spatial analysis there were performed in this study in order to achieve the objectives of this study. Figure 5 shows the sequence of spatial analysis performed in this study.

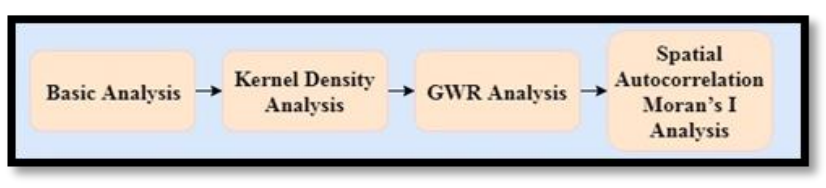

Figure 5. Sequence of spatial analysis

\subsubsection{Demographic Statistical Analysis}

This study presents demographic variables of the respondents as a demographic statistical analysis. Although it was not part of the purpose of the study, this set of data was intended to describe demographic variables of the sample and to assess any influence on the study findings. The demographic data consisted of gender, age, ethnicity, locality, level of education, current occupation, and monthly income. In order to analyze the distribution of each variable, data collected is organized according to the occurrence of different results in each polling district.

\subsubsection{Kernel Density Analysis}

The density analysis using Kernel method is selected to determine the concentration of each issue that influenced youth voters in each polling district. This analysis was performed by using data collected to create hot spot maps of spatial concentration of issues influenced. There are nine issues being examined in this study as shown in Table 2.

\begin{tabular}{|l|l|}
\hline No. & Issues influencing youth voters \\
\hline 1. & Cost of living \\
\hline 2. & Settlements and housing \\
\hline 3. & Water and environmental issues \\
\hline 4. & Job opportunity issues \\
\hline 5. & $\begin{array}{l}\text { Implementation of NBOS; RTC, UTC, 1 Malaysia } \\
\text { brand and others issues }\end{array}$ \\
\hline 6. & Economic recovery / price of goods' issues \\
\hline 7. & Corruption governance \\
\hline 8. & Religious empowerment (example: ACT 355) \\
\hline 9. & Petrol price \\
\hline
\end{tabular}

Table 2. Issues influencing youth voters in Nusajaya

\subsubsection{GWR Analysis}

In this study, the correlation between assessment of state political figures with socio-demographic variables and the issues influence youth voter is identified by using geographically weighted regression analysis (GWR). Local regression analysis, also called GWR, uses the information for each point to derive a local model (Fotheringam et al. 2002). Regression analysis is a related technique used to assess the relationship between dependent variable and the explanatory variable or independent variable.

GWR analysis is used to model, examine, and explore spatial relationships, between respondents' assessment of state political figures and the factors behind observed spatial patterns, to predict outcomes based on the GWR model. However, there are two types of assessment of state political figures as shown in Table 3. In this paper, assessment of state political figures as outcomes or dependent variable while explanatory variables are identified by using exploratory regression.

\begin{tabular}{|l|l|l|l|}
\hline No. & Political Figures & Caliber & Non-caliber \\
\hline 1. & $\begin{array}{l}\text { Dato' Sri Mohd Najib Tun } \\
\text { Hj. Abdul Razak }\end{array}$ & $/$ & $/$ \\
\hline 2. & $\begin{array}{l}\text { Dato' Seri Dr. Ahmad } \\
\text { Zahid Hamidi }\end{array}$ & $/$ & $/$ \\
\hline 3. & $\begin{array}{l}\text { Datuk Seri Dr Wan } \\
\text { Azizah Wan Ismail }\end{array}$ & $/$ & $/$ \\
\hline 4. & $\begin{array}{l}\text { Tuan Guru Dato' Seri Haji } \\
\text { Abdul Hadi bin Awang }\end{array}$ & $/$ & $/$ \\
\hline 5. & $\begin{array}{l}\text { Tun Dr. Mahathir bin } \\
\text { Mohamad }\end{array}$ & $/$ & $/$ \\
\hline 6. & $\begin{array}{l}\text { Tan Sri Dato' Muhyiddin } \\
\text { Hj. Mohammad Yassi }\end{array}$ & $/$ & $/$ \\
\hline 7. & Dato' Seri Anwar Ibrahim & $/$ & $/$ \\
\hline 8. & Tan Kok Wai & $/$ & $/$ \\
\hline 9. & Mohamad Sabu & $/$ & $/$ \\
\hline 10. & Lim Kit Siang & $/$ & $/$ \\
\hline 11. & Lim Guan Eng & $/$ & $/$ \\
\hline
\end{tabular}

Table 3. Types of assessment to state political figures 
All types of assessment of politicians have been modeled using appropriate variables for modelling by using GWR.

In this study, assessment of state political figures as outcomes or dependent variable $(\mathrm{Y})$ while explanatory variables $(\mathrm{X})$ are identified by using exploratory regression. These variables are used to examine and explore spatial relationships, to give better understanding of the factors behind observed spatial patterns and to predict $\mathrm{Y}$ based on that understanding.

Assessment of political figure for non-caliber category used demographic profiles and issues that influenced youth voters' perception as explanatory variables. Assessment of political figure for caliber category used demographic profiles and voting factors as explanatory variables.

\subsubsection{Spatial Autocorrelation Model}

Spatial autocorrelation analysis is used on the model residuals and to find spatial pattern in order to develop a properly specified model. The spatial autocorrelation tool tests to see if the residuals exhibit spatial clustering or random pattern. Figure 6 shows spatial autocorrelation report for GWR analysis.

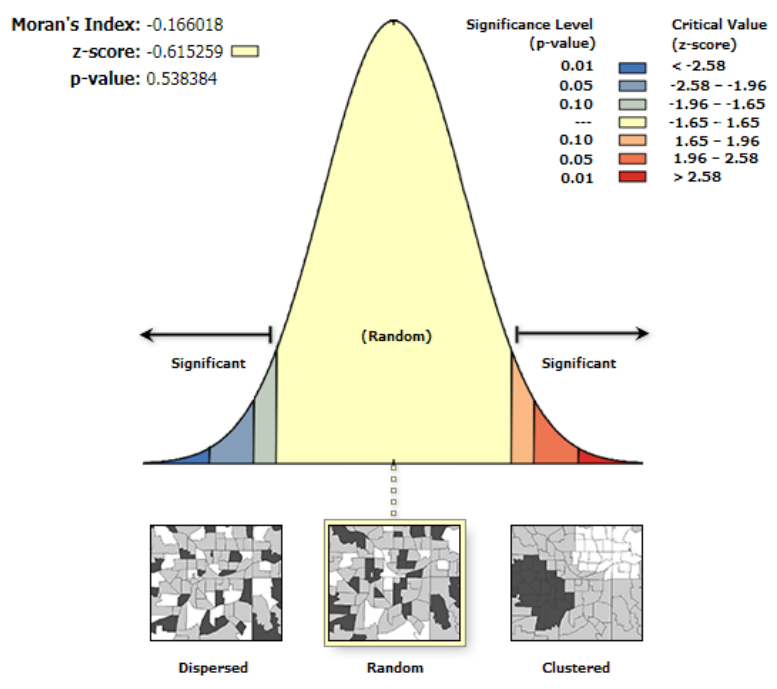

Given the z-score of -0.615259008289 , the pattern does not appear to be significantly different than random.

Figure 6. Spatial autocorrelation report for GWR analysis

\section{RESULT AND DISCUSSION}

The final output for each analysis were executed from four spatial analysis performed in this study. Analysis approaches are used in order to give best result and better understanding and performance. The entire analyses were performed and produced using ArcGIS software.

\subsection{Demographic Statistical Analysis}

Questionnaires were given to youth voter aged between 21 to 40 years. The data from the questionnaires were statistically analysed. The findings are discussed according to the questionnaire. In order to have a complete questionnaire, respondents were asked to tick demographic category.

Although it was not part of the purpose of the study, this set of data was intended to describe demographic variables of the sample and to assess for any influence on the study findings. The demographic data consisted of gender, age, ethnicity, level of education and income. Data related to gender of the respondents is presented in Figure 7.

It is quite clear that out of the total respondents investigated for this study, nearly half (58 per cent) were females whereas about $42 \%$ were males. In Malaysian social conditions, the households are normally headed by females and head of the household was the unit for data collection; from the given sample, very few households are headed by males.

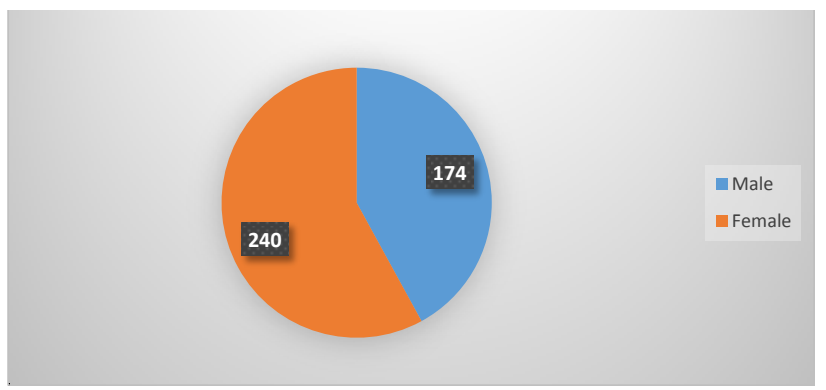

Figure 7. Distribution of respondents by gender

The respondents were asked how old they were, and hence into what age range they belonged. This question was asked to ensure the respondents were in youth voter group. Figure 8 depicts the respondents' ages.

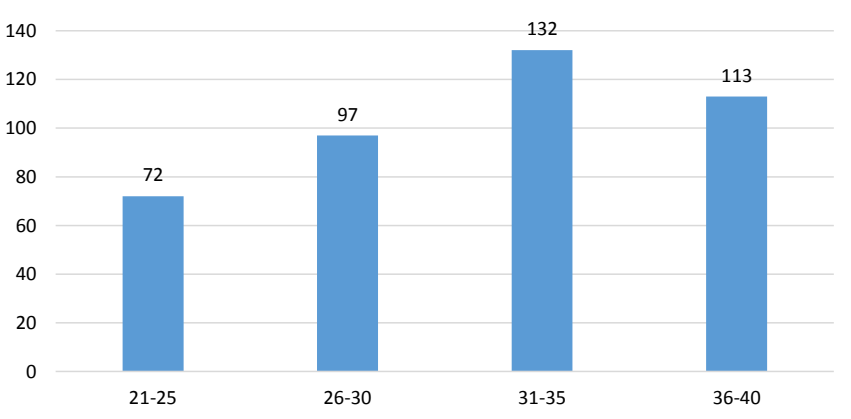

Figure 8. Depiction of respondents by age

The range of age was found to be 19 years starting from 21 to 40 years. Nearly $17 \%$ are in range 21 to 25 years of age. There are 97 respondents aged 26 to 30 years. In term of age groups, the respondents aged 26 to 30 comprise $23 \%$ of the total and 36 to 40 years show $27 \%$ of the total. To be more specific, large number of respondents are in range 31 to 35 years of age in the sample.

Education is one of the most important characteristics that might affect the person's perceptions and the way of looking and understanding any particular social phenomena. The variable 'Educational level' was investigated in this study and the data pertaining to education is presented in Figure 9.

Figure 9 shows that approximately $40 \%$ of the respondents were educated up to Diploma/STPM and relatively fewer of them, $4 \%$, were educated up to primary school level and $18 \%$ were educated up to post graduate level. $38 \%$ of the respondents were educated up to the secondary school level. It can be concluded from the figure above that, by and large, the respondents were progressive in education but they were still far away from the 
higher education, which is so important today to create a knowledge-based society.

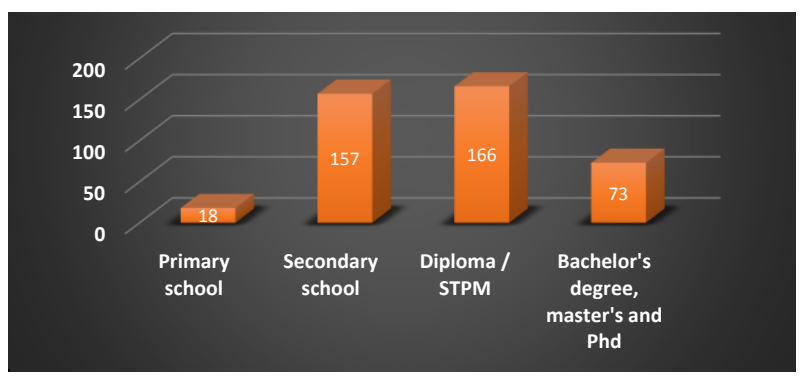

Figure 9. Distributions of respondents by level of education

The study normally includes those demographic variables which are assumed to have explanatory value in the study. Demographic characteristics such as age, gender, race, level of education, household income, and highest education are the important factors for the present study.

\subsection{Kernel Density Analysis (KDA)}

In this analysis, nine issues are used to identify the spatial concentration of issues that influenced youth voters at each polling district. The issues that have been analysed in this study are mainly economic issues, religious polemics, civil liberties, and democratization that took place.

Several locations are found to be denser in this analysis, which indicates that the various locations have issues that influenced youth voters' perception as shown in figure below. The hot spot shows colour gradient, which is yellow through red. Red area shows the higher density, while yellow depicts that the location has lower density of issues that influenced youth voters' perceptions. These colours are used to depict the issues influencing youth voters at each polling district.

Cost of living issues shows the highest spatial concentration in several locations. Thus, all locations of each polling district with greater density are indicators of the hot spot location. The hot spot location for cost of living issues are Pertanian, Kebangsaan, and Kemuliaan. However, there are some potential areas that might contribute to cost of living issues, which are Gelang Patah Utara and Tanjung Kupang. The result of hot spot map for cost of living issues can be seen in Figure 10.

Similarly, with cost of living issues, economic recovery or price of goods' issues shows Pertanian, Kebangsaan, Kemuliaan, Gelang Patah Utara and Tanjung Kupang are geographical areas that contain the higher density compared to the other locations, which is presented in Figure 11.

For water and environmental issues, Figure 12 shows the red gradient have greater tendency on the top map of polling district boundary. KDA shows that Kangkar Pulai, Pertanian, Kebangsaan and Kemuliaan depict the affected areas for this issue. However, Gelang Patah Utara, Sungai Melayu and Tanjung Kupang show similarity to the spatial concentration for this issue.

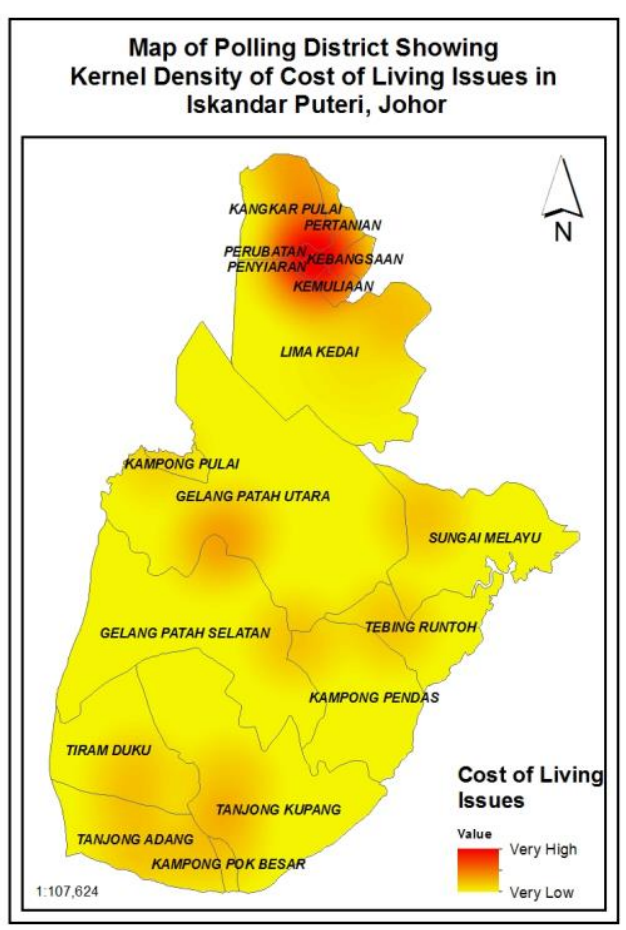

Figure 10. Result of the hot spot maps using KDA for cost of living issues

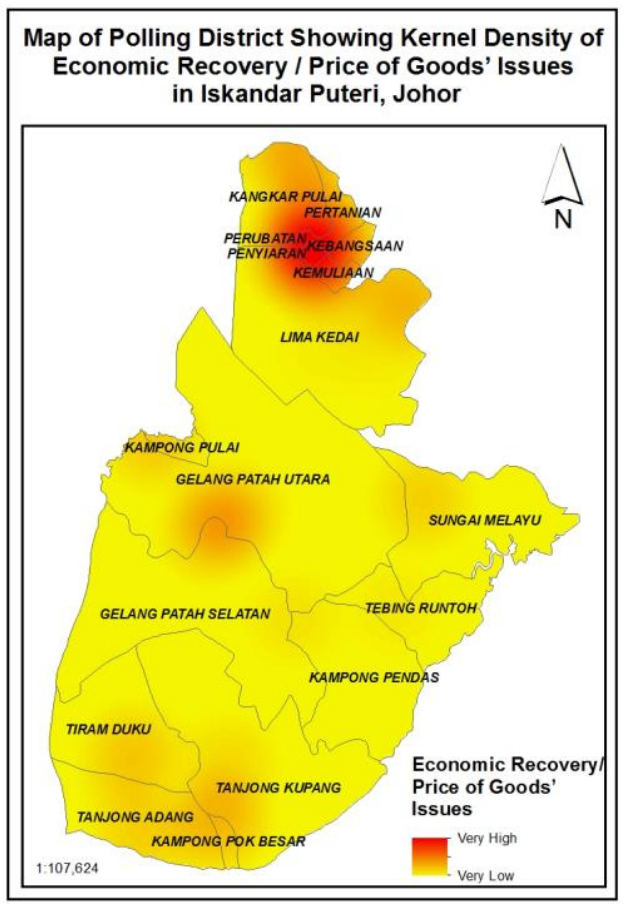

Figure 11. Result of the hot spot maps using KDA for economic recovery and price of goods' issues 


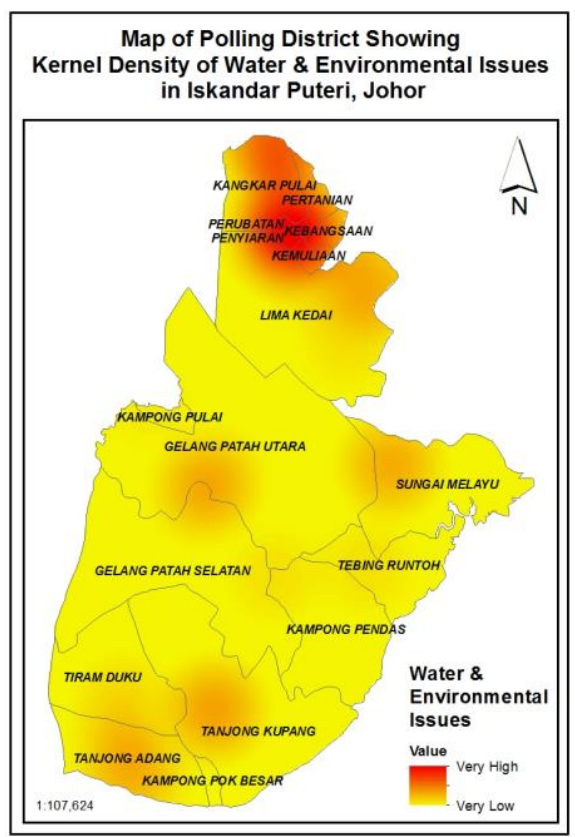

Figure 12. Result of the hot spot maps using KDA for water and environmental issues

Fiure 13 shows the result of the hot spot maps for settlement and housing issues depicts only several locations appeared to have high density issues. Three locations, Kebangsaan, Kemuliaan and Gelang Patah Utara, have potential to be affected by the issues examined since the location indicates hot spot area on each location.

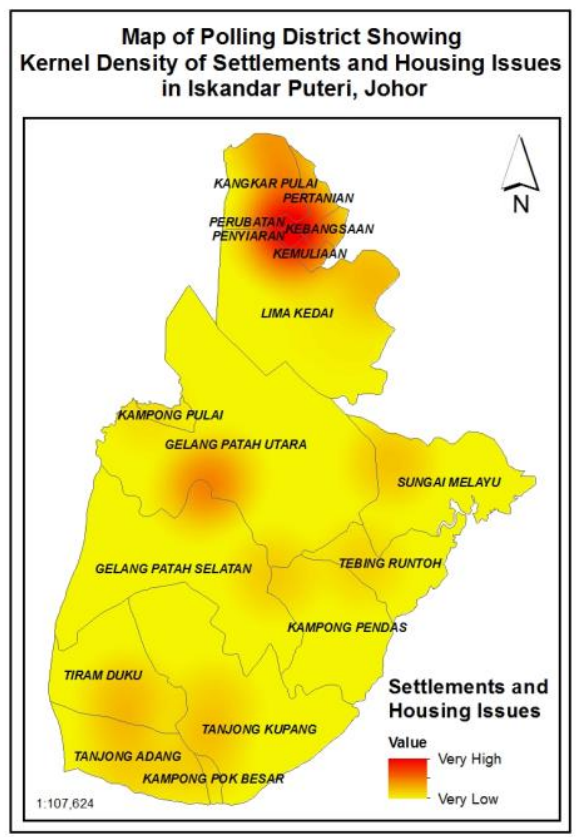

Figure 13. Result of the hot spot maps using KDA for settlement and housing issues

It is important to identify the location of respondents who are influenced by various issues where this can be better presented as hot spot maps of affected area. Three issues, which are job opportunity issues, petrol price issues, and implementation of
NBOS; RTC, UTC, 1 Malaysia brand and others issues are shown in Figure 14, 15 and 16. High density on the top of the maps is due to population distribution of the respondents. However, the result showed majority of respondents expressed their thought on the issues.

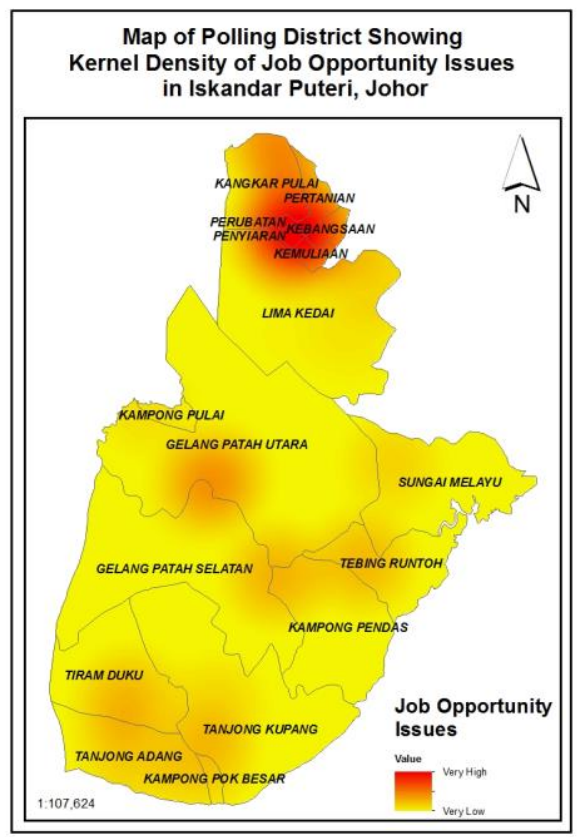

Figure 14. Result of the hot spot maps using KDA for job opportunity issues

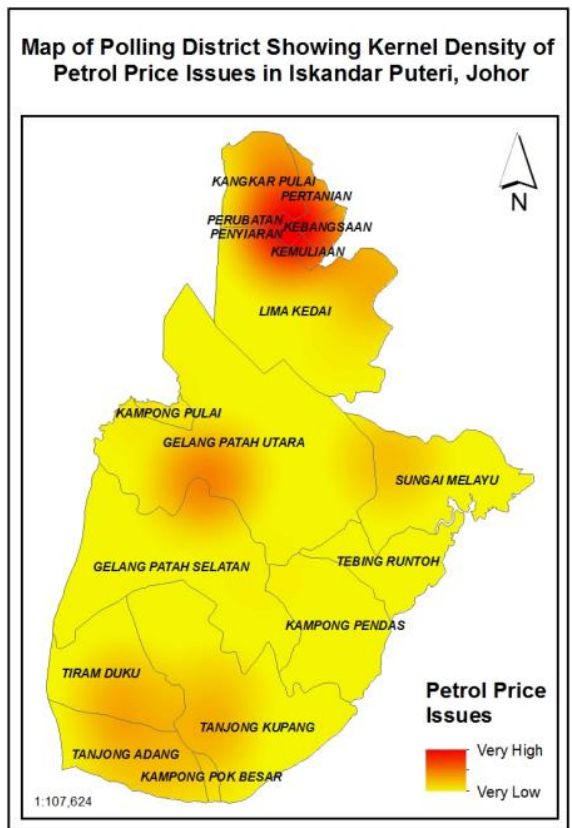

Figure 15. Result of the hot spot maps using KDA for petrol price issues 


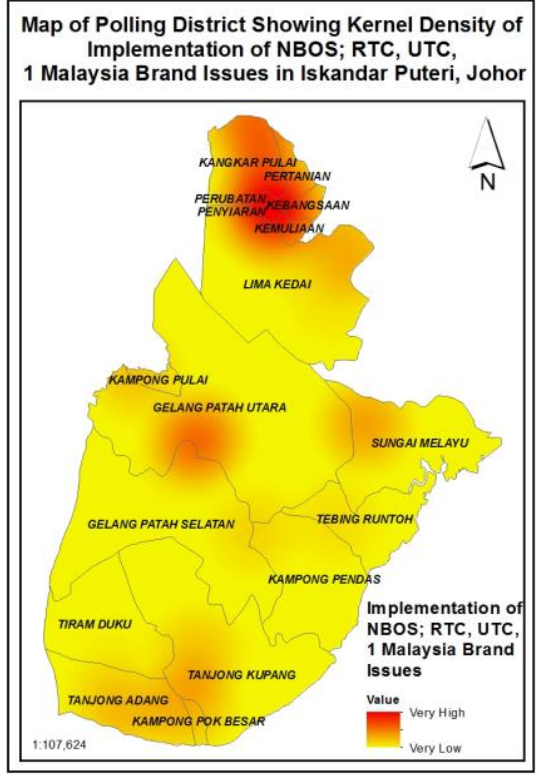

Figure 16. Result of the hot spot maps using KDA for implementation of NBOS; RTC, UTC, 1 Malaysia brand and others issues

Although various issues have been examined, petrol price issues and implementation of NBOS; RTC, UTC, 1 Malaysia brand and other issues show majority of polling district locations have higher concentration probably due to the contentious issues.

Figure 17 shows the findings of the analysis based on KDA for corruption governance issues, which indicated three locations, Kemuliaan, Penyiaran and Kebangsaan show highest concentration on this area. These areas are located approximately 8 kilometers from each other. Moreover, Pertanian, Perubatan, Penyiaran and Kemuliaan are areas that show hot spot area for job opportunity issues.

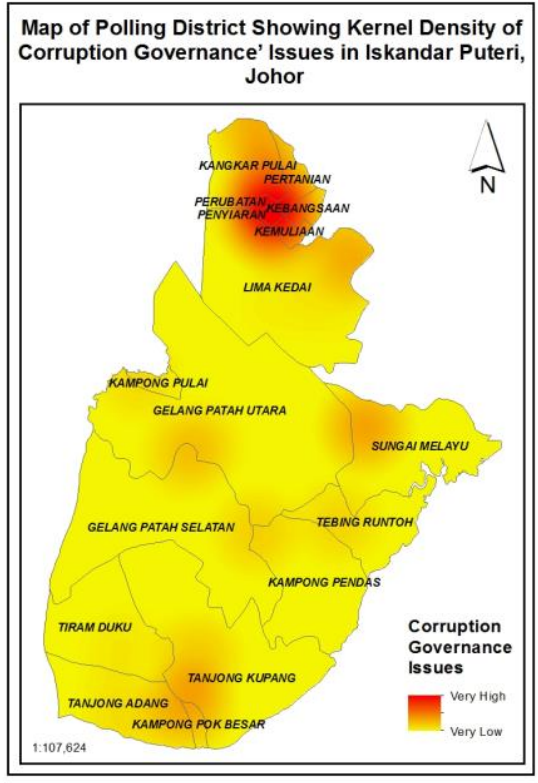

Figure 17. Result of the hot spot maps using KDA for corruption governance issues
Religious empowerment (example: ACT 355) is the last issue to have been examined in this study. The indicators are very alarming, especially for Malay, because this study believed this issue involved in youth voters' perception. The higher concentration of this issue can be seen in Kangkar Pulai, Pertanian, Kebangsaan, Kemuliaan, Gelang Patah Utara and Kampong Pok Besar areas. Figure 18 represents the hot spot maps for religious empowerment issue.

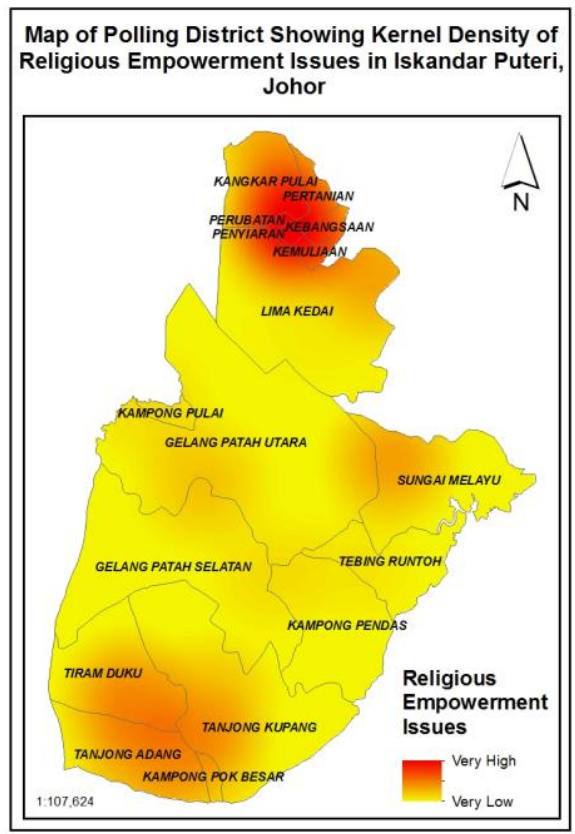

Figure 18. Result of the hot spot maps using KDA for religious empowerment issues

The findings of the analysis based on the issues that influenced youth voters in Nusajaya indicated 382 respondents said the issues which have been examined vary by each polling district. There are nine hot spot maps executed from this analysis. This analysis are used to visualize geographic data, which is polling district in Nusajaya, in order to show areas where a higher density of issues influenced youth voters.

\subsection{GWR Analysis}

In GWR analysis, assessment of state political figures as dependent variable. To find what factors contribute to this assessment, exploratory regression tool is used. The highest value indicates the strong relationship between variables selected with assessment of political figures. Hence, the highest value is selected as explanatory variable. This value is unique for each political figure and reached the statistical significance.

Assessment of political figure for non-caliber category used demographic profiles and issues that influenced youth voters' perception as explanatory variables. Assessment of political figure for caliber category used demographic profiles and voting factors as explanatory variables.

The Local R2 (R2) values range from 0.5 and 0.9 , which indicate strong relationship between the variables selected, simultaneously the model performing well. Figure below shows the results of local regression with spatial pattern for each political figure. 
Figure 19 shows that two factors contributed for assessment of Dato Seri Najib (DSN). Respondents believe factor of racial unit and local candidate are the main factors to assess the DSN. The findings also found that majority of Malay and Bumiputera agreed that DSN is a politician of caliber. Based on level of education, respondents with a highest level of education are contributors to the assessment of caliber for DSN.

For non-caliber assessment, by using ER tools, cost of living and housing issues are the important issues to show why respondents assess DSN as non-caliber figure. Moreover, respondent with education from primary school is one of the factors for the assessment.
Figure 20 shows explanatory variables used in order to see the relationship between variable selected and assessment for Dato' Seri Hadi Awang (DSHH). Low tax, local candidate and similarity nation factors are factors that contributed for assessing DSHH as caliber political figure. Therefore, respondents with level education in primary and secondary school are also the factor behind this assessment.

The local R2 values show that cost of living, water and environmental, and job opportunity issues are the main issues contributed to DSHH assessment for non-caliber political figure. Additionally, this analysis found that government servants have a negative perception towards DSHH.

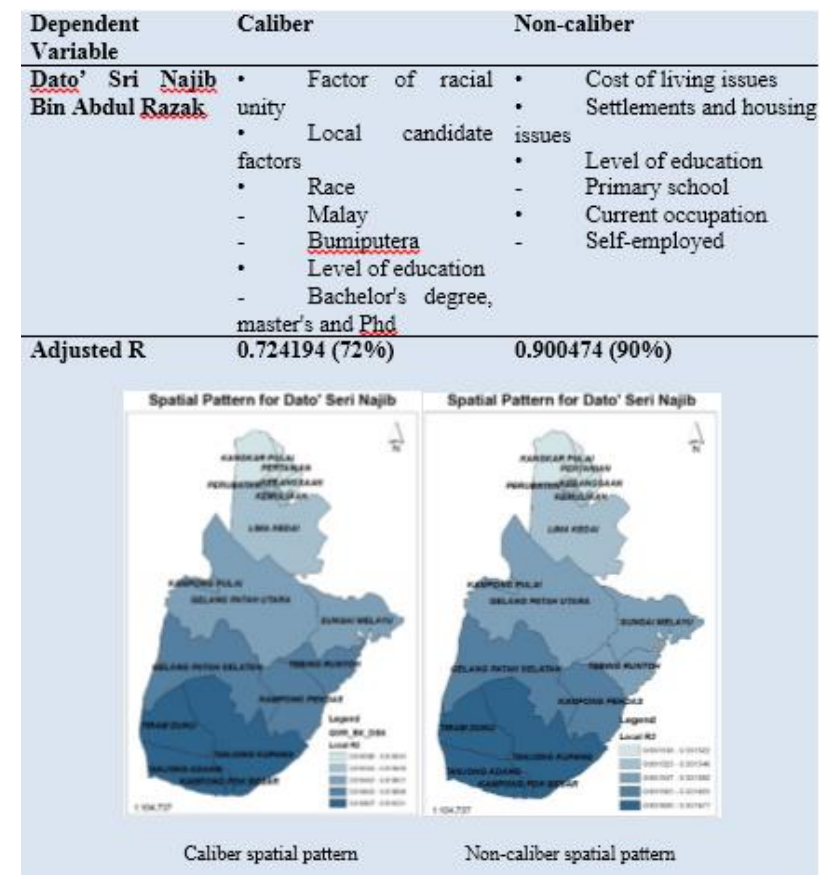

Figure 19. Explanatory variable for Dato' Seri Najib assessment

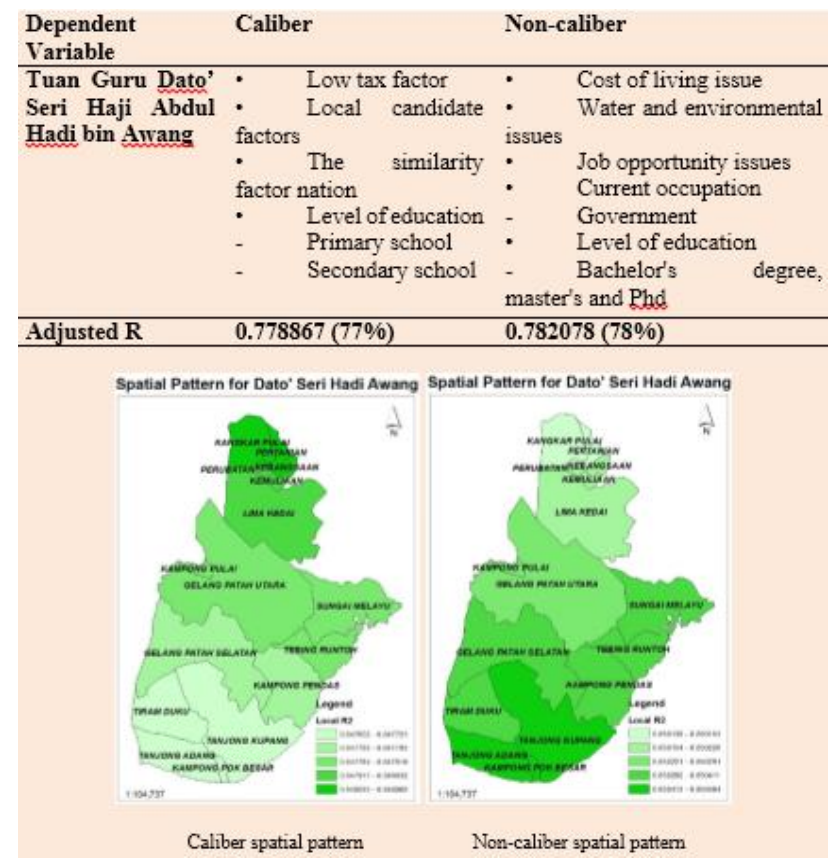

Figure 20. Explanatory variable for Dato' Seri Hadi Awang 
Figure 21 shows spatial pattern for Tun Dr. Mahathir Mohamad (TDM) with explanatory variable used to assess TDM. There are three factors selected, which are low tax, similarity nation and local candidate factors. This can be assessed by Chinese voters and respondents that had secondary school as the highest level of education.

The findings for the assessment of TDM for non-caliber political figures show that cost of living, Chinese and Indian voters, respondent who are self-employed and jobless are the main factors that contributed to non-caliber political figure for TDM.
Figure 22 shows the explanatory variables used in assessing Dato' Seri Anwar Ibrahim (DSAI). There are five factors that contributed for assessing DSAI as political figure. There are importance and reward factor, candidate's background and personality factor, similar nationality factors. Moreover, Indian voters and respondents with secondary school level of education are also factors that contributed to this assessment.

However, water and environmental issues, job opportunity issues and implementation of NBOS, RTC issues, and current occupation factors are main issues that contributed to assessment for non-political figure for DSAI.

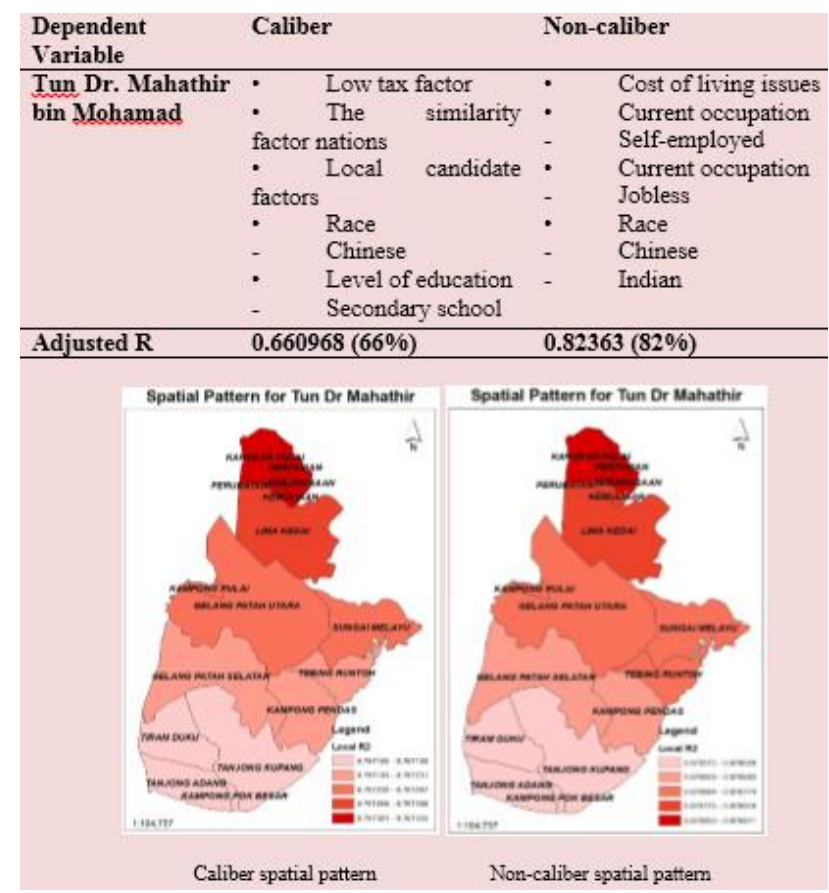

Figure 21. Explanatory variable for Tun Dr. Mahathir Mohamad

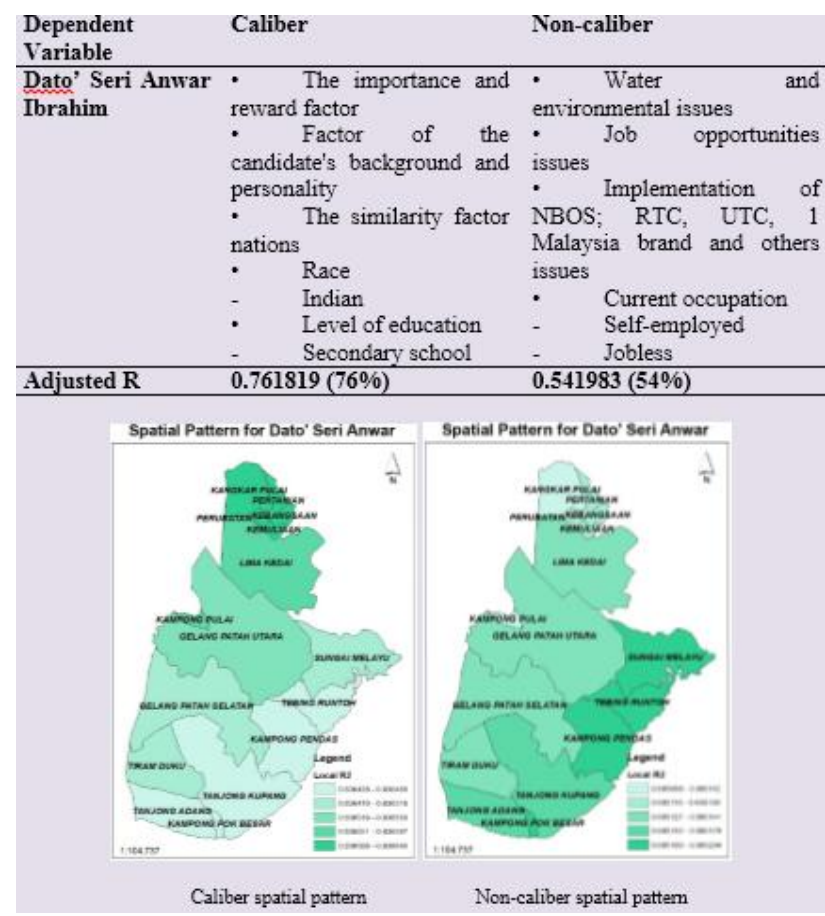

Figure 22. Explanatory variable for Dato' Seri Anwar Ibrahim 
Figure 23 shows spatial pattern for Lim Guan Eng (LGE) with explanatory variable used. There are three factors selected, which are importance and reward factor, factor of maintaining religion and nation and Health care factor. Chinese voters and respondents that had primary school as the highest level of education also contributed to the LGE assessment for caliber political figure.
Assessment of LGE for non-caliber political figures shows that economic recovery issues, housing issues and implementation of NBOS and others issues are the main factors that contributed to non-caliber political figure for LGE. Moreover, current occupation and level of education factors also contributed to assessment for LGE.

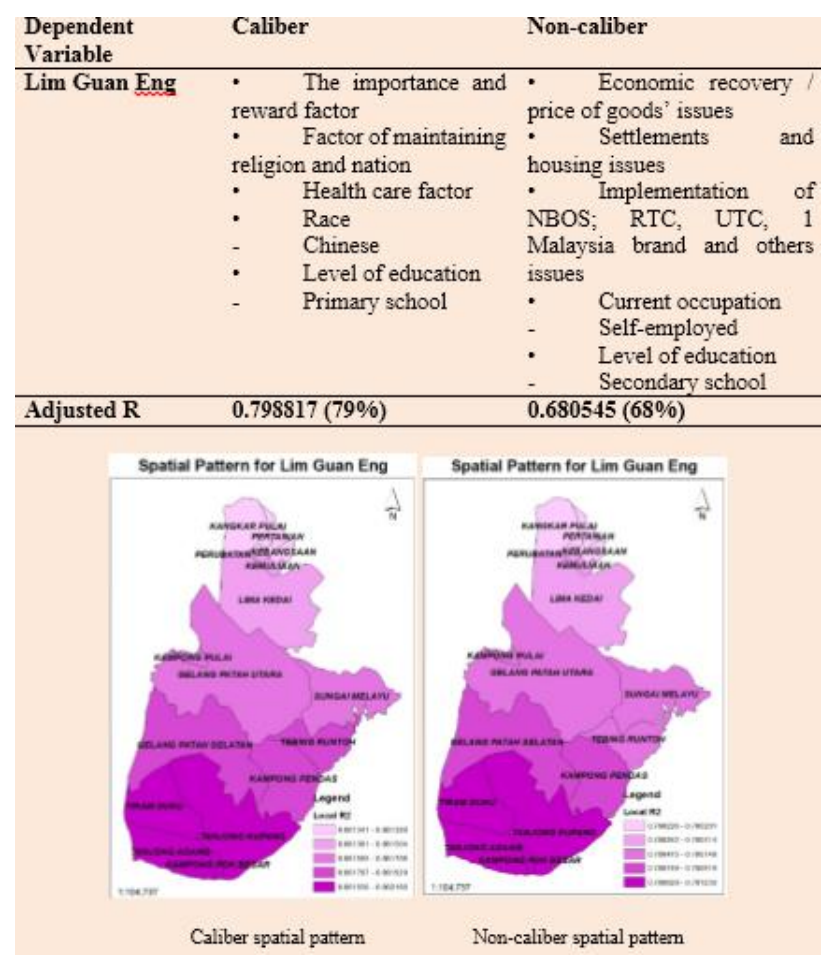

Figure 23. Explanatory variable for Lim Guan Eng

The overall results of local regression suggest a positive relationship between the assessment of political figures and the following variables, which indicates correlation among the variables that have been tested. The result obtained show that all the adjusted R2 value is much higher than $50 \%$, indicating this model explains strong relationship between variables that have been used.

\subsubsection{Spatial Autocorrelation Moran's I Analysis}

Results from spatial autocorrelation analysis shows that the residuals are random, which means it is good results (over or under predictions). In order to have a properly specified model, spatial autocorrelation tool on the model residuals are used to find a random spatial pattern. Figure below represents the results of spatial autocorrelation report.

Figure 24 shows the analysis of Moran's I index of GWR residuals. This figure showed a spatial autocorrelation report of regression residuals, which suggests the misspecification of the model due to non-stationary of the spatial process.

The values of Moran's I for DSN and DSHH show positive autocorrelation. The result obtained from model application on GWR residuals for DSN and DSHH show that positive spatial autocorrelation values tended to occur in adjacent areas.
A GWR model residual model for TDM and DSAI found the residuals had positive spatial autocorrelation which p-value is less than 0.1. GWR residuals model for TDM and DSAI show that the spatial arrangement is completely random.

In the regression methods, there is a part of variance that is not explained by the model and the regression residuals for LGE. Spatial autocorrelation for LGE show that the model is assumed to be dispersed. However, the model still performed well as the Local R2 values indicate positive values.

The overall result using appropriate test statistic using Moran's I showed that GWR residuals model for all the political figures performs moderately well with reasonably random residuals. However, there is little evidence of any autocorrelation in the model.

This analysis was designed to detect possible problem with proper specification of the model. However, given that the errors for a well-fitted model are randomly distributed across a study area, Moran's I coefficients for each political figure indicate positive spatial autocorrelation. 


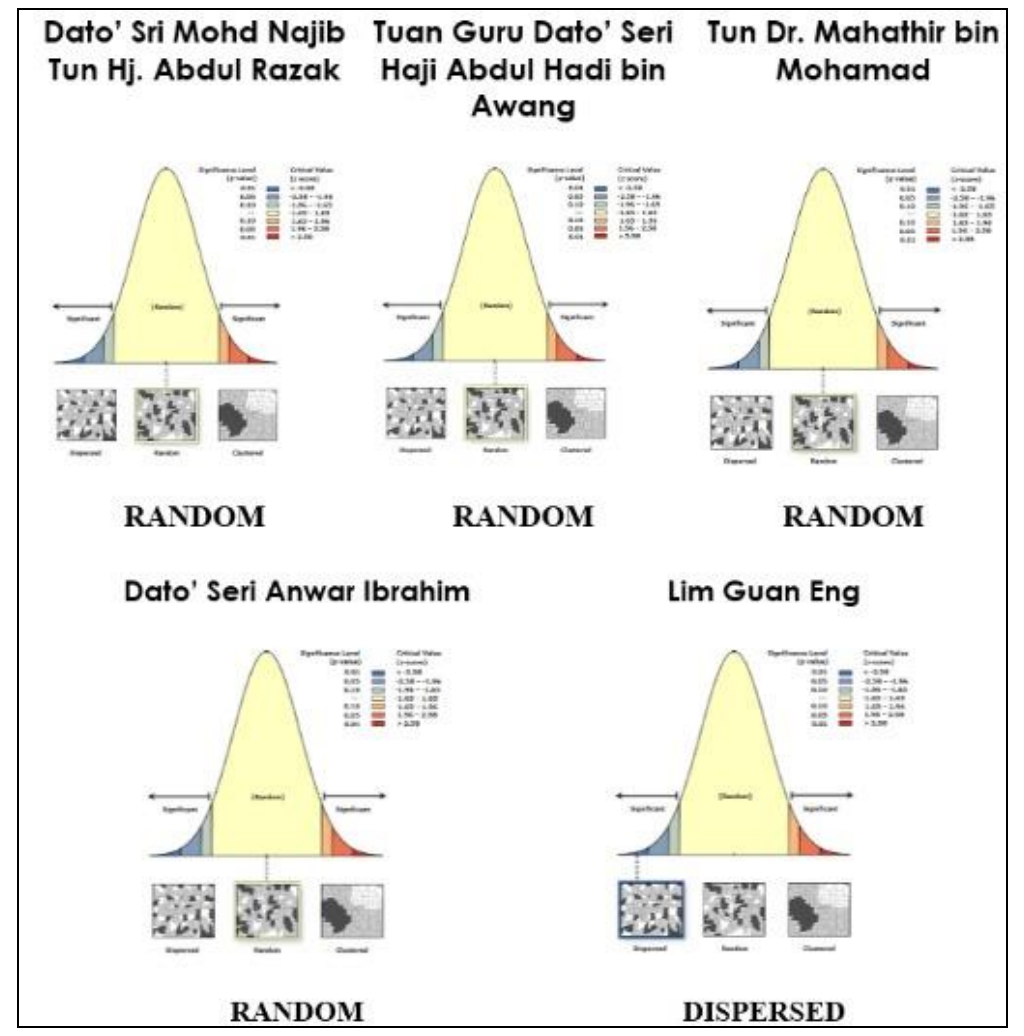

Figure 24. GWR model residuals for assessment to political figures

\section{CONCLUSION}

First, this study addresses characteristics and interactions of the essential elements involved in an election process. Various issues exist, which if seen from different angle, provide different perceptions. This study discussed issues that have been carefully selected, however, almost all of the issues are pertaining to the social issues. Therefore, due to the influence of stakeholder, voters' perception are used in this study to analyze these issues by taking the initiative to seek the perception of youth voters through user requirement analysis.

Next, various definitions of democratization and perception are used in order to provide better understanding of each subject matter. Previous studies have demonstrated that voters' perception are important influences on trustworthiness and acceptance so that it can be converted in the form of a vote. A review of the literature on the subject illustrates that the voting process can be more effective using GIS technology.

Furthermore, this study explored election features from a geographical perspective as the focus of this study. This study carried out the applicability of GIS-based spatial analytical procedures in election analysis. For the analysis, spatial distribution of youth voters' perception was depicted by means of choropleth maps. This gives a quick visual idea of the areal or spatial pattern of party stronghold. This spatial analysis illustrates the value of GIS in analyzing election analysis as GIS provides an exceptionally powerful analytical tool in examining various aspects.

Finally, the purpose of this chapter is to provide a summary of the overall study to determine whether or not the study meets the objectives. The objectives of this study have been identified and the findings of the data collected discussed. This chapter also addressed the limitations of the study, which includes three aspects. Finally, three recommendations were proposed for the better improvement in future study. The results from this recommendation may be extended to other results and can be made to improve the results. In addition, the results from this election analysis can be improved by finding a better approach in order to allow for more detail in this study.

\section{ACKNOWLEDGEMENTS}

The authors would like to acknowledge TindakMalaysia for providing open-access data of electoral boundary in Gelang Patah area. This study was supported by Research Fund by Research University Grants under GUP Q. J130000.2627.13J88 from Universiti Teknologi Malaysia.

\section{REFERENCES}

Aun, W. M. (1999). The Malaysian Legal System. Selengor, Darul Ehsan: Addison Wesley Langman Malaysia SDN. BHD. $(4409-\mathrm{W})$.

Teacher, Law. (November 2013). Malaysian Practices Of Parliamentary Democracies Administrative Law Essay. Retrieved from https://www.lawteacher.net/free-lawessays/administrative-law/malaysian-practices-of-parliamentarydemocracies-administrative-law-essay.php?cref $=1$

Afgan F., (2016). Political Elections as an Element of Democracy. Journal of Political Sciences \& Public Affairs 4(4), $1-3$. 
Iep.utm.edu,. (2015). Karl Popper: Political Philosophy Internet Encyclopedia Of Philosophy. Retrrieved 5 December 2015, from http://iep.utm.edu/popp-pol/

Nizah, M. A. M., (2016). Selangor Voters Perception toward Issues in 13th Malaysian

Baharudin, A. M. (1989). Politik Melayu abad 21. Kuala Lumpur: 'D' Enterprise Md.

Bartholdi J. J. (1992). How Hard Is It To Control An Election? Georgia Institute Of Technologu, Atlanta, GA 30330, U.S.A, Vol. 16, 27-40.

Kuhne W. (2010). The Role of Elections in Emerging Democracies and Post-Conflict Countries. International Policy Analysis

The Report Of The Global Commission On Elections, Democracy And Security. (2012). Retrived From http://www.kofiannanfoundation.org/supporting-democracyand-elections-with-integrity/global-commission-on-electionsdemocracy-security-2/

Hai L. H. (n.d.). Electoral Politics in Malaysia: 'Managing Elections in a Plural Society'. Electoral Politics in Southeast and East Asia, 101-147

Franklin M (2004) Voter Turnout and the Dynamics of Electoral Competition in Established Democracies Since 1945. New York: Cambridge University Press.

Ezrow L. (2016). Satisfaction with democracy and voter turnout: A temporal perspective. Party politics, 22(1), 1-14.

Catt. H. (2005). Children and young people as citizens: Participation, provision and protection. University Of Otago.

Kerr, David (2003) Citizenship Education in England: The Making of a New Subject - OJSSE 2/2003.

Berry R., Dunleavy P. (2012). Engaging young voters with enhanced election information, Democratic Audit. Retrieved From : http://www.democraticaudit.com/

Quintelier E. (2007). Differences In Political Participation Between Young And Old People. Contemporary Politics, 14(2), 165-180.

G. Parry, G. Moyser and N. Day, Political Participation and Democracy in Britain, Cambridge, 1992.

J. Bessant, 'Mixed Messages: Youth Participation and Democratic Practice', Australian Journal of Political Science, Vol. 39, No. 2, 2004, pp. 387- 404; Eden and Roker, op. cit.

Rise Of Young Voters Shifts Malaysia Election Balance (2013). Retrieved From https://www.reuters.com/article/us-malaysiaelection-youth/rise-of-young-voters-shifts-malaysia-electionbalance-idUSBRE93S0XU20130429

Vasil, R. . (1972). The Malaysian General Election of 1969. The Journal of Asian Studies (Vol. 33). Kuala Lumpur: Oxford University
Rogers, M. L. (1977). Sungai Raya: A Sociopolitical Study of a Rural Malay Community. Center for South and Southeast Asia Studies.

Kamlin, M. (1977). History, politics, and electioneering: the case of Terengganu.

Kassim, I. (1978). The Politics of Accomodation: An Analysis of the 1978 Malaysian General Election.

Md. Salleh Md. Gaus, . (1984). Politik Melayu Pulau Pinang, 1945-1957. Dewan Bahasa dan Pustaka, Kementerian Pelajaran. Goh Cheng Teik, . (1994). Malaysia: Beyond Communal Politics. Pelanduk Publications.

Mohammad Agus Yusoff, . (1992). Politik Akomodasi di Sabah 1962-1992. Sabah: Laser Skill Sdn. Bhd.

Chin Ung-Ho, . (1996). Chinese Politics in Sarawak: A Study of the Sarawak United People's Party. Oxford University Press, Inc.

Mohamed Abu Bakar, . (1980). Communal Parties and the Urban Malay Vote: Perspectives from Damansara. In . Harold Crouch, . Lee Kam Hing, \& . Michael Ong (Eds.), Malaysian Politics and the 1978 Election. Kuala Lumpur: Oxford University Press.

Ghazali Mahyudin, . (1999). Teori Sains Politik Pilihan: Aplikasinya dalam Konteks Malaysia. (G. Mahyudin, Ed.). Universiti Kebangsaan Malaysia (UKM).

Mohd. Fuad Mat Jali, ., \& Junaidi Awang Besar, . (2005). Kajian Corak Pengundian di Pilihanraya Kecil Pengkalan Pasir. Bangi

Syed Arabi Idid, ., \& Safar Hashim, . (1993). Pilihan Raya Umum: Satu Perspektif Komunikasi Politik. Kuala Lumpur: Dewan Bahasa Dan Pustaka

Syed Arabi Idid, ., \& Mazni Buyong, . (1995). Malaysia's General Election 1995: People, Issues, and Media Use. Bangi: Universiti Kebangsaan Malaysia (UKM).

Dahlberg, S. (2009). Voters' Perceptions of Party Politics. Department of Political Science University of Gothenburg, Sweden, 74.

Institut Darul Ehsan perkukuh politik ilmu. (2017, April 8). Sinar Harian. Retrieved from http://www.sinarharian.com.my/mobile/wawancara/institutdarul-ehsan-perkukuh politik-ilmu-1.656397

Ramani, S. (2014, April 22). What sways the urban voter? India Together. Retrieved from http://indiatogether.org/gismapping-of-urban-voting-behaviour-government

Hanewicz, C. (2012). Geographic Information Systems and the Political Process.

Revised August 2018 